\title{
Jeg er pneuma, lysende og stoflig
}

\author{
Review-artikel
}

ANDERS KLOSTERGAARD PETERSEN

\author{
Troels Engberg-Pedersen, \\ Cosmology \& Self in the Apostle Paul. The Material Spirit, \\ Oxford, Oxford UP 2010, \\ 287 sider, $£ 65$.
}

På én og samme tid er det en udfordrende og problemfyldt bog, Troels Engberg-Pedersen (TEP), en af de i dag internationalt fremmeste Pauluslæsere, har skrevet. Den er værd at opholde sig ved, fordi den gennem en ambitiøs analyse af Paulus bryder ny jord i studiet af den tidlige Kristusbevægelse, og fordi den (omend problemfyldt) tematiserer et grundproblem i antropologi og religionsvidenskab: Hvor bogstaveligt skal de 'primitive' forstås? Begrebet optræder ganske vist ikke i bogen, men diskussionen har sine steder umiskendelige ligheder med forne dages primitivismedebat og fremhævelse af den religiøse oplevelse.

Bogens anledning er formentlig den kritik, som er blevet Engberg-Pedersens teologiske disputats, Paul and the Stoics (2000), til del. I al fald kan bogen læses som en fordringsfuld videreudvikling af hovedpointer i disputatsen (jf. s. 176, 248f, note 7), ligesom den fortsætter forfatterens og andre forskeres bestræbelse på endegyldigt at gøre op med jødedom-hellenisme-modstillingen. ${ }^{6}$ I centrum står to tanker. For det første ønsket om at sprænge jødedom-hellenisme-kontrasten i en grad, så også den hævdvundne modstilling mellem apokalyptik og filosofi fortoner sig (jf. s. 76, 107, 123, 137). Man kan med andre ord ikke lege eksegetisk eller idé- og religionshistorisk kispus, hvor man bortretoucherer bestemte elementer hos Paulus under henvisning til, at de hører hjemme i en anden åndshistorisk sammenhæng, mens man positivt reificerer andre traditioner og gør dem teologisk bærende. Hos Paulus gælder det som hos Go-

6 Se fx den af Engberg-Pedersen redigerede antologi Paul Between the Judaism/Hellenism Divide, Louisville, KY, Westminster John Knox 2001. 
ethe: "Wie alles sich zum Ganzen webt, Eins in dem andern wirkt und lebt!" For det andet har TEP en ambition om at vise, hvordan traditionelle læsninger af Paulus ikke i tilstrækkelig grad har taget ham for pålydende, men alt for hurtigt er forfaldet til metaforiske læsninger (jf. s. 52, 55, 71f, 83, 152, 174f). Skal man gribe Paulus, er det afgørende at forstå hans apokalyptisk kosmologiske forestillinger og hans tanker om Kristustilhængernes forvandling konkret (jf. s. 248, note 5). Det er ikke mindst på det punkt, TEP blandt andet under inspiration fra Bourdieu udvikler sin tidligere forståelse. En adækvat Paulustolkning må også have kroppen og den religiøse oplevelse med, hvis den ikke skal komme til kort (s. 181, 207). Hvor TEP i 2000-afhandlingen ensidigt fokuserede på kognitive dimensioner hos Paulus med relation til antropologi og etik, forsøger han i 2010 at 'råde bod' på den manglende besindelse på det 'religiøse'. Det er det 'tunge' religiøse arsenal som 'ånd', 'Kristus' opstandelse', 'Guds indgriben i verden', 'Kristustilhængernes opstandelse', etc., som nu føres på bane. I den nye bog skal de aspekter, der manglede i den tidligere, bringes i overensstemmelse med - eller måske snarere - uddybe forståelsen fra den gang.

Bogen har seks kapitler. Det første intonerer bogens to hovedmotiver. For det første viser TEP gennem analyse af 1 Kor 15, hvordan Paulus' forestilling om pneuma (ånd) er et helt igennem stofligt og kropsligt fænomen. For det andet bruger han Filon og Visdommens Bog til at demonstrere, hvordan Paulus' basale synspunkt ikke alene var foreneligt med, men også påvirket af stoisk monisme og materialisme. Kap. 2 udfolder dette synspunkt ved at bringe det i anvendelse på en lang række andre Paulustekster. Det paukes ind hos læseren, hvordan Paulus' pneuma-forestilling skal forstås bogstaveligt og kosmologisk. Her lades al afmytologisering ude! I kap. 3 om verden, kognition og superhumane aktører bringes hovedpointen fra 2000-afhandlingen i overensstemmelse med de første to kapitlers insisteren på at læse Paulus bogstaveligt og 'religiøst' . Det gælder også i forhold til de for en moderne forståelse særprægede ideer om kosmiske magter som fx Satan og dæmoner. I det følgende kapitel om guddommelig og menneskelig frihed og handlen tematiseres problemstillingen om, hvordan mennesket kan tænkes som et frit handlende væsen, hvis det grundlæggende er bestemt af guddommelige magter. Nøglen til besvarelse af spørgsmålet hentes på ny fra stoicismen, nemlig hos Epiktet. Det kognicerende eller - hos Paulus - pneumatiske menneske befinder sig i en situation, der sprænger kontrasten mellem guddommelig underkastelse og menneskelig frihed, fordi de to i antikken ikke blev set som modsætning, men som to alen af samme stykke (s. 137). I bogens to sidste kapitler introduceres moderne filosofiske perspektiver, nemlig Bourdieu og Foucault. Kap. 5 retter blikket mod tre forhold: 1) Paulus' såkaldte 'omvendelsesoplevelse' og Kristustilhængernes tilsvarende kognitive og fysiske forandring; 2) formaningerne som feltet, hvor Kristustilhængernes forvandling finder sted; 3) brevskrivningen, der som praksis iscenesætter Paulus' selvbeskrivelse som forbillede for Kristustilhængerne. De tre temaer perspektiveres i lyset af begreberne 'religiøs oplevelse'; 'selv' og 'habitus'. Det er her, Foucault (diskussionen om selvet) og Bourdieu (habitus-begrebet) bringes på bane. I det afsluttende kap. 6 sammenfattes bogens hovedtanker med særlig fokus på spørgsmålet om "Paulus' 
kropslige praksis under brevskrivningen" - 2 Kor 1-7 får i den sammenhæng en hovedrolle.

Så langt så godt. Der er meget positivt at sige om bogen, som på flere felter virkelig tænker nyt; men jeg synes samtidig, at den er båret af nogle grundlæggende problemer. Jeg deler TEPs ønske om at nedbryde den kategoriale kontrast mellem hellenisme og jødedom udspillet som en modsætning mellem filosofi og apokalyptik. Jeg finder også, at TEP modificerer misforståelige tanker fra den tidligere bog. Fx understreger han flere steder ædrueligt, at Paulus naturligvis hverken var filosof eller skrev filosofisk (jf. s. 6, 102, 249, note 7); men det hindrer ikke, føjer jeg til, at hans begrebsverden kan oversættes til filosofiske kategorier, ligesom man også kan pege på grundmotiver og tankestrukturer, som er fælles for begge verdener. Alligevel sidder jeg tilbage med en fornemmelse af, at TEP - ovennævnte forbehold til trods - i flere formuleringer går et skridt videre og hævder, at Paulus de facto tænkte stoisk:

Thus the claim was that Stoicism and Pauline thought are not just two patterns of thought that happen to resemble one another, but that Paul had used a number of basic ideas in Stoic ethics (together with a large number of other, non-Stoic ideas derived from other corners of Paul's context) to articulate his own message, which was, of course, not just a Stoic one" (min kursivering, s. 176, jf. s.179, 219, note 76).

Det er jeg af flere grunde skeptisk over for, ligesom jeg stiller mig tvivlende over for den filosofihistoriske fortælling, der skal legitimere forståelsen. Man kunne med megen ret, som det er blevet gjort af andre kolleger, ${ }^{7}$ hævde, at Paulus' tænkning snarere end på væsentlige punkter at ligne stoicisme udviser paralleller med platonisme. Det er ikke tilfældigt, at den skarpsynede Nietzsche med særlig sans for Paulus kaldte kristendom for 'platonisme for folket'. ${ }^{8}$ TEP er opmærksom på problemet, men får det blandt andet reduceret gennem sin fremhævelse af, at middelplatonismen var gennemsyret af stoicisme (se fx s. 98). Det er givetvis på nogle punkter rigtigt; ${ }^{9}$ men jeg synes ikke desto mindre, at TEP lægger en for tyk stoisk fernis ned over forfattere som i al fald Filon.

Mere problematisk er imidlertid den bogstavelige læsning af Paulus og ikke mindst ønsket om via de paulinske breve at nå tilbage til et eller andet oplevelsesniveau, som i analysen skal bruges som omdrejningspunkt for Paulus' appel til brevmodtagerne

7 Se fx G.H. van Kooten, Paul's Anthropology in Context. The Image of God, Assimilation to God, and Tripartite Man in Ancient Judaism, Ancient Philosophy and Early Christianity, WUNT 232, Tübingen, Mohr-Siebeck 2008.

8 F. Nietzsche, Friedrich Nietzsche. Werke in Vier Bänden, Salzburg, Verlag das Bergland-Buch 1985, vol. 4, Jenseits von Gut und Böse, 156.

9 TEP henviser generelt til John Dillons klassiker fra 1977, The Middle Platonists. 80 B.C. to A.D. 220. Revised edition with a new afterword, Ithaca, Cornell UP 1996, hvor Dillon flere steder peger på stoiske tanker hos tænkere, som sædvanligvis rubriceres middelplatonikere. Det gælder fx i Dillons afsnit om Filon, se Dillon 1996, 148-52. 
om i religiøs oplevelse at efterligne ham (se fx s. 168). Selvsagt er TEP opmærksom på, at der hos Paulus ikke er nogen omvendelsesberetning. Paulus forstod sin bevægelse mod Kristuskulten som profetisk kaldelse til at reformere sin fædrene religion (jf. Gal 1,13-17 og Fil 3,4-11, se s. 142, 147). Alligevel kaldes Paulus' specifikke beskrivelse af sin kaldelse bogen igennem for 'omvendelse' (s. 142, 153, 158, 162, 164, 183, 190). Jeg forstår heller ikke, hvordan TEP gennem retorisk gennemkomponerede tekster vil forsøge at nå bag om dem til en eller anden religiøs oplevelse uden at gå mere indgående ind i diskussionen af sådanne beretningers stereotype karakter (det gælder også i forhold til lidelseskataloger og den berømte 'jeg'-fremstilling i Rom 7). Det er som om, han selv er sig problemet bevidst:

\footnotetext{
It is also true that one must not start out from the idea of a phenomenology of religious experience that one hopes might yield an understanding of it that lies before any given description of it, as it were 'inside' or as the kernel of all descriptions. That is clearly a mistake. Instead, one should start from the 'outside' in the form of the given description of a religious experience in the conceptual language in which it is given. To a large extent one should also stay there. Still, one should not in principle give up the idea that accounts of religious experiences may be accounts of something-for instance, as perhaps in the case of Paul, of bodily changes of which the possessors of those bodies are themselves aware (s. 144).
}

Problemet bliver ikke mindre, når jeg sammenholder det med TEPs hovedambition, nemlig en revitalisering af en bogstavelig læsning af Paulus' kosmologiske forestillinger og tanker om en basal forandring. Jeg synes, det på centrale punkter ligner en tilbagevenden til slutningen af 1880'erne og begyndelsen af 90'erne til den tidlige Göttinger-skoles optagethed af oplevelseskategorien med alle de problemer, det indebar.

J.Z. Smith, som TEP i anden sammenhæng citerer, har skrevet en væsentlig artikel om metaforisering i en religiøs kontekst og om primitivismediskussionen i antropologi og religionsvidenskab generelt. ${ }^{10}$ Her skriver han lakonisk om bororomænds (et brasiliansk indianerfolk) forestilling om at være papegøjer: "How should the historian of religion interpret a religious statement which is apparently contrary to fact? The Bororo is not a parrot-as one psychiatrist noted, presumably applying the ultimate test of speciation, "he does not try to mate with other parakeets"."11 Jeg har flere gange under læsning af bogen måttet tage mig i at tænke på Smiths essay i let omskrevet form: "Jeg er pneuma, lysende og stoflig!"

Jeg er enig med TEP i, at Paulus sandsynligvis har opfattet en række af sine forestillinger betydelig mere bastant og konkret, end vi gør i dag; men derfra og til at ophæve

10 J.Z. Smith, "I Am a Parrot, (Red)," Map Is Not Territory. Studies in the History of Religion, SJLA, Leiden, Brill 1978, 265-288.

11 Ibid. s. 267. 
metaforiseringen er der et stykke vej. Bogen savner en generel teoretisk drøftelse dels af grænserne mellem bogstavelighed og metaforisering, dels af konteksten for Paulus' påstande. For der er selvsagt grænser for bogstaveligheden. Når Paulus om de Kristustilbedende hævder, at de i dåben er korsfæstet med Kristus, ved han godt, at der er tale om en metafor (jf. Rom 6,4.6), ligesom hans udsagn om, at menigheden er Guds tempel (jf. 1 Kor 3,16) dårligt kan opfattes bogstaveligt. Det ved TEP selvfølgelig godt (til en vis grad, se fx s. 162, 174f), men han får hverken analytisk eller teoretisk foretaget en grænsedragning. Det nærmeste, man i bogen kommer en drøftelse af problemet, er en let troskyldig passage, hvor religiøs metaforik blandt andet sammenlignes med en metafor som 'bordben':

\footnotetext{
However, and this is the basic point, it is possible far more often than people normally take it to be the case to understand Paul to be also referring, by the use of these metaphorical expressions, to concrete, bodily events that can be spelled out directly in the physical language of his cosmology. In that case, one has to be extremely careful about taking him to be speaking 'only metaphorically' (s. 175, jf. s. 83, 122, 150, 154, 169).
}

Naturligvis, fristes man til at sige, kan religiøse udsagn ikke være andet end metaforiske, eftersom de pålægges en naturlig verden, hvis fortolkning de søger at overdeterminere. Det gjorde allerede Durkheim klart for snart 100 år siden i Les Formes élémentaires. Det reducerer dog ikke religiøse udsagn og verdensforståelser til blot metaforiske. Er der en ting, man kan lære af Durkheim og den efterfølgende tradition, er det netop, hvordan religiøse udsagn trods deres basale metaforicitet i eminent forstand kommer til at udgøre den bogstavelige virkelighed for de religiøse udøvere. Religiøse forestillinger overdeterminerer (i bestemte sammenhænge) ${ }^{12}$ religiøse udøveres oplevelse af den empirisk tilgængelige virkelighed. Et af TEPs hovedproblemer forsvinder således som dug for solen, hvis man tænker det ind i en klassisk religionsvidenskabelig teoridannelse, som i øvrigt uproblematisk kan suppleres af nyere kognitionsteori.

Jeg er enig med TEP i, at de paulinske udsagn i Paulus' verden skal forstås bogstaveligt, men ikke i den ligefremme forstand TEP gør det. Så har man glemt grundlæggende indsigter fra Durkheim og Smith. Det er da også tankevækkende, at TEP ikke foretager bevægelsen fra en bogstavelig læsning af de paulinske udsagn til en egentlig forklaring af dem; for man kan efter min mening ikke blive stående ved dem, medmindre man ender i den Smith'ske parodi: "Jeg er pneuma, lysende og stoflig." TEP har i stedet nogle ejendommelige formuleringer, hvor han afviser mulige indvendinger mod hans bogstavelige læsning ved at henvise til, at han har Paulus på sin side: "I can imagine that this reading (sc. Paulus som overfører sin pneuma til adressaterne gennem pneumatisk erfaringssprog!) will be roundly rejected by scholars. I can only reply that

12 Om balkaniseringen, dvs. menneskers kontinuerlige pendlen mellem forskellige virkelighedsrepræsentationer, se mit essay "Religiøs modenhed eller Sancho Pancha til hest," Psyke \& Logos 26.2 (2005), 543-558. 
I have a strong sense that exactly here we are extremely close to Paul's own understanding of what is going on in this text. If he were present, he would have nodded" (s. 168f, jf. s. 173). Ja, så kan man da dårligt tillade sig at være uenig!

Og så et hjertesuk på falderebet. Der er meget godt at sige om det peer-reviewsystem, man de seneste år har indført i forskningsverdenen. Kvaliteten af bidrag i tidsskrifter og antologier hos de estimerede forlag har været stigende. En bagside af systemet er imidlertid, når man binder antal publikationer og bevillinger sammen. Så skal man være en både selvbåren og egensindig forsker for at modstå fristelsen til at publicere hurtigt og småt. TEPs monografi er i den sammenhæng tidstypisk. Den er sammensat af fem tidligere bidrag, som - sat på spidsen - har fået smurt et tyndt lag sammenhængende fernis nedover sig og dertil en afsluttende epilog (kap. 6). Der er rigtignok tematisk konsistens i fremstillingen, ligesom de enkelte kapitler fremstår helstøbt, men det er ikke en fra begyndelsen ordentlig gennemtænkt monografi. Dertil er der for mange digressioner og svinkeærinder, ligesom man som læser undertiden savner fremstillingens røde tråd. Jeg synes, det er trist, hvis det på grund af peer-reviewsystemet er den form, monografier fremover skal antage. Jeg klandrer selvsagt ikke TEP for problemet. Hans 'monografi' er blot i den sammenhæng et tidstypisk fænomen - ikke mindst internationalt. Men det er kreperligt, at et politisk gennemført system er godt på vej til inden for en kulturvidenskabelig kontekst at ødelægge den videnskabelige monografi som genre.

TEP har tilegnet sin bog til Dale Martin, som med sin bog om 1 Kor. fra 1995, The Corinthian Body, har været en af de væsentligste eksponenter for og bidragydere til det nye Paulusperspektiv. Det forstår man godt. Til gengæld kan jeg ikke afholde mig fra en lettere undren over selve dedikationen, il miglior fabbro ('den bedre håndværker'). Det var den dedikation, Eliot tilegnede Ezra Pound i The Waste Land. Skal den forstås så 'bogstaveligt', at TEP er Eliot og Martin Pound, eller kan man nøjes med en metaforisk fortolkning af den som udtryk for taknemmelighed? Jeg håber det sidste.

Det er i sandhed en udfordrende og ambitiøs bog, TEP har begået. Jeg er som fremgået skeptisk over for dens anslag og flere hovedpointer; men det ændrer ikke, at den ægger til tænkning og modsigelse. Og det er vel ikke det ringeste, man kan sige om en bog.

Anders Klostergaard Petersen, lektor, cand.theol. Afdeling for Religionsvidenskab, Aarhus Universitet 